\title{
CHILDHOOD OSTEOPOROSIS AND PRESENTATION OF TWO CASES WITH OSTEOGENESIS IMPERFECTA TYPE V OSTEOPOROZA V OTROŠKI DOBI IN PREDSTAVITEV DVEH BOLNIKOV Z OSTEOGENESIS IMPERFECTA TIPA V
}

\author{
Nina BRATANIC ${ }^{1}$, Bojana DZODAN ${ }^{1}$, Katarina TREBUSAK PODKRAJSEK ${ }^{2,4}$, Sara BERTOK ${ }^{1}$, \\ Barbara OSTANEK ${ }^{3}$, Janja MARC ${ }^{3}$, Tadej BATTELINO ${ }^{1,4}$, Magdalena AVBELJ STEFANIJA ${ }^{1, *}$ \\ ${ }^{1}$ University Children's Hospital, Department of Pediatric Endocrinology, Diabetes and Metabolic Diseases, \\ Bohoriceva 20, 1000 Ljubljana, Slovenia \\ ¿University Medical Centre Ljubljana, University Children's Hospital, Unit for Special Laboratory Diagnostics, \\ Vrazov trg 1, 1000 Ljubljana, Slovenia \\ ${ }^{3}$ University of Ljubljana, Faculty of Farmacy, Askerceva 7, 1000 Ljubljana, Slovenia \\ ${ }^{4}$ University of Ljubljana, Faculty of Medicine, Vrazov trg 2, 1000 Ljubljana, Slovenia
}

\begin{abstract}
Keywords: bone mineral density, hypertrophic callus, IFITM5 gene, bisphosphonates

Introduction. Osteogenesis imperfecta $(\mathrm{OI})$ is etiologically heterogeneous disorder characterized by childhood osteoporosis. A subtype Ol type $V$ is caused by the same c. -14C>T mutation in the IFITM5 gene. Nevertheless, there is a marked interindividual phenotypic variability in clinical presentation; however, response to bisphosphonates is reported to be good.

Methods. Two individuals with OI type $\mathrm{V}$ had multiple recurrent fractures with hypertrophic calluses, scoliosis and ossifications of the forearm interosseous membranes. Sequencing of IFITM5, genotyping of variants rs2297480 in farnesyl diphosphate synthase gene (FDPS), and rs3840452 in geranylgeranyl diphosphate synthase 1 gene (GGPS1), both involved in bisphosphonate metabolism, was performed.

Results. In patient $1 \mathrm{BMD}$ reached normal values during bisphosphonate treatment and remained normal four years after the treatment discontinuation. In patient 2 no increase in BMD after five years of bisphosphonate treatment was observed and callus formation continued. The c.-14C>T IFITM5 mutation in heterozygous state was detected in both individuals. Additionally, both patients carried FDPS variant rs2297480 in homozygous state, and were heterozygous for GGPS 1 variant rs3840452.
\end{abstract}

\section{IZVLEČEK}

Ključne besede: mineralna kostna gostota, hipertrofični kalus, gen IFITM5, bisfosfonati

Conclusions. The paper presents a short overview of childhood osteoporosis with a special emphasis on OI type $\mathrm{V}$ by presenting two cases. Both $\mathrm{OI}$ type $\mathrm{V}$ patients had identical disease-causing mutation, but marked interindividual phenotypic variability. The striking failure in response to bisphosphonate treatment in one of the patients could not be explained by the variants in genes involved in bisphosphonate metabolism.

Uvod. Osteogenesis imperfecta (OI) je vzročno heterogena bolezen, katere značilnost je osteoporoza $v$ otroštvu. Pri vseh opisanih bolnikih s podtipom Ol tipa $V$ je vzrok bolezni ista mutacija c.-14C>T gena IFITM5. Kljub temu med bolniki obstaja izrazita fenotipska variabilnost $v$ klinični sliki, toda opisan je le dober odgovor na zdravljenje z bisfosfonati.

Metode. Oba bolnika z Ol tipa V sta imela ponavljajoče se zlome kosti s hipertrofičnimi kalusi, skoliozo in zakostenelo membrano med podlahtnico in koželjnico.
Opravili smo sekvenčno analizo gena IFITM5 in genotipizacijo variant rs2297480 gena za farnesil difosfat sintazo (FDPS) in rs3840452 gena za geranilgeranil difosfat sintazo 1 (GGPS1), ki sta vpletena v presnovo bisfosfonatov.

Rezultati. Pri bolniku 1 se je ob zdravljenju z bisfosfonati mineralna kostna gostota povečala do normalnih vrednosti in ostala nespremenjena štiri leta po prenehanju zdravljenja. Pri bolniku 2 kljub pet let trajajočemu zdravljenju z bisfosfonati ni prišlo do izboljšanja mineralne kostne gostote, še naprej so se pojavljali zlomi kosti in hipertrofični kalusi. Pri obeh bolnikih smo ugotovili znano mutacijo c. $-14 C>T$ v genu IFITM5 $v$ heterozigotni obliki. Oba imata $v$ homozigotni obliki prisotno tudi varianto rs2297480 gena FDPS in $v$ heterozigotni obliki varianto rs3840452 gena GGPS1.

Zaključek. $V$ članku je predstavljen kratek pregled osteoporoze $v$ otroštvu s posebnim poudarkom na OI tipa $\checkmark$ pri dveh bolnikih. Pri obeh bolnikih z Ol tipa V, ki sta imela različno klinično sliko in potek bolezni, smo ugotovili mutacijo c. $-14 C>T$ v genu IFITM5. $Z$ analizo genov encimov, vpletenih $v$ presnovo bisfosfonatov, nismo mogli pojasniti neuspešnega zdravljenja z bisfosfonati pri enem od bolnikov.

*Corresponding author: Tel: +386 31511 546; E-mail: magdalena.avbelj@mf.uni-lj.si 


\section{INTRODUCTION}

Osteoporosis is a skeletal disorder characterized by decreased bone mass and micro-architectural deterioration that leads to fragile bones and susceptibility to fracture.

Although osteoporosis is considered to be primarily a disorder of adults, there is evidence to suggest that its roots may actually lie in childhood. Adolescence represents a significant time period in bone formation and is described as the 'bone bank' of the future. Approximately $40 \%$ of bone mass is accumulated in adolescence and peak bone mass is attained in early adulthood $(1,2)$. Future bone health and the risk of osteoporosis in adulthood are significantly related to the bone mass that accumulates in adolescence through early adulthood.

The assessment of bone density can be an important and informative investigation in a child with suspected osteoporosis. The most frequently used modality is dual energy X-ray absorptiometry (DXA) due to its availability, speed of scan acquisition and low radiation dose (3).

The definition of osteoporosis in adults is based on bone mineral density measurements, primarily through DXA. A measurement that falls 2.5 standard deviations (SD) or more below the average value of a young healthy adult defines osteoporosis (4). The Pediatric Position Development of the International Society for Clinical Densitometry (ISCD) (2007) definition of osteoporosis is bone mass that is less than 2 SD ( $z$-score) below the average value for age and gender-matched controls, and a significant fracture history, such as long bone fracture of the lower extremities, vertebral compression fracture and two or more long bone fractures of the upper extremities (5). DXA underestimates the true density of small bones and overestimates that of large ones, which is why a height-for-age $z$-score adjustment produces the least bias correction on areal BMD measures (6).

Fractures are common in healthy youth. By 16 years of age, almost one-half of boys and one-third of girls have sustained a fracture (7). The clinical challenge lies in the early discrimination of children with fractures due to underlying skeletal pathology.

Low BMD ascertained by DXA associates with fracture in youth (8), but a fracture threshold has not been as well established in children as it was in adults.

Multiple factors play a role in bone health, such as genetics, family history, nutrition, particularly calcium and vitamin D intake, hormonal status and physical activity.

Osteoporosis in children may be primarily the result of intrinsic bone abnormality. It is usually either genetic in origin, or secondary to an underlying medical condition and/or its treatment (Table 1).
Table 1. Classification of childhood osteoporosis (9).

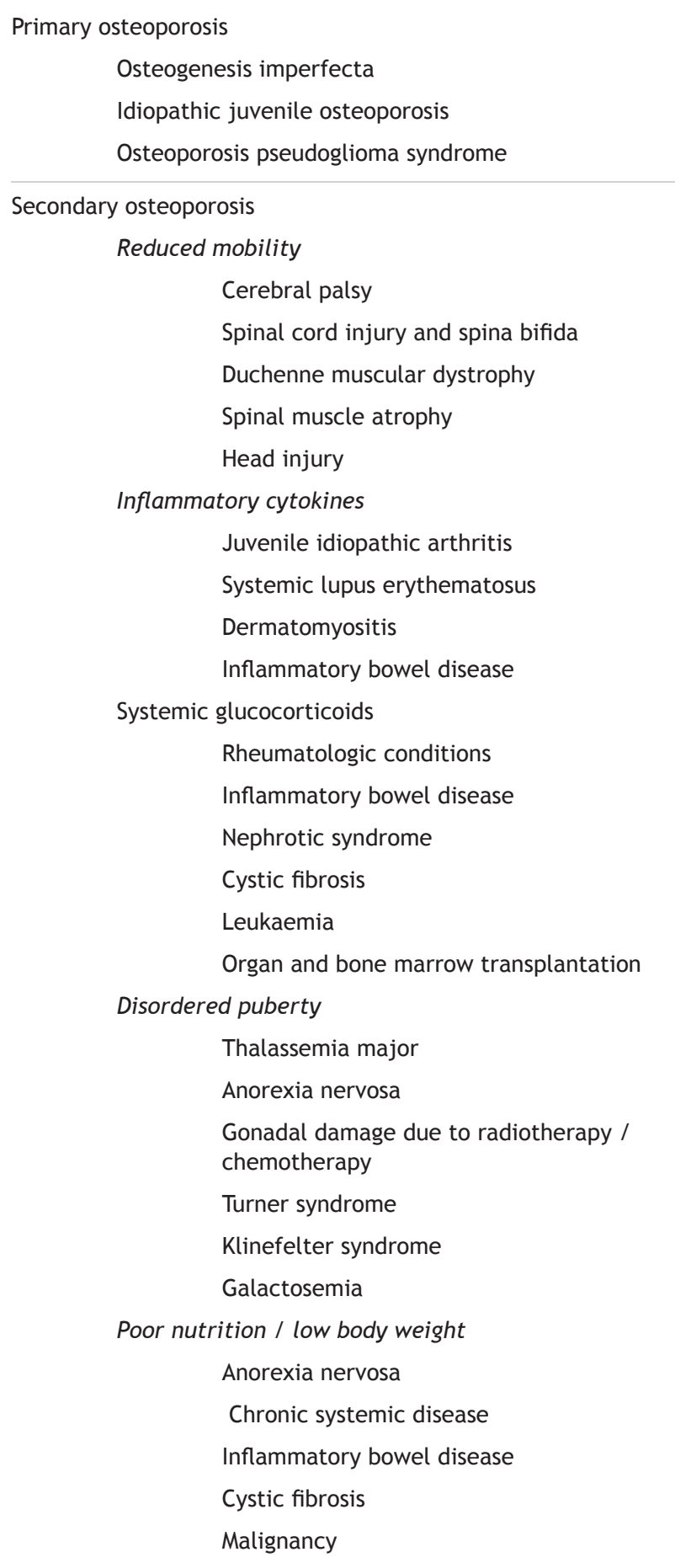

Osteogenesis imperfecta $(\mathrm{OI})$ is a heritable bone dysplasia, characterized by bone fragility and deformity and growth deficiency. The International Society of Skeletal Dysplasias suggested OI classification that differentiates five types based on clinical characteristics and severity (Table 2) (10). Currently, 15 genes are associated with OI, as reviewed by Valadares et al. and Marini et al. $(11,12)$. The 
majority of patients with OI display autosomal dominant inheritance of the mutations in the type I collagen genes, COL1A1 and COL1A2. During the past several years, a number of non-collagenous genes whose protein products interact with collagen have been identified as the cause of rare forms of OI $(11,12)$. The majority of the nonclassical Ol types have autosomal recessive inheritance. The exceptions are X-linked inheritance of the PLS3 gene mutations associated with Ol type 1 (13), and a unique dominant defect in the gene encoding interferon-induced transmembrane protein 5 (IFITM5), which is associated with Ol type $\mathrm{V}$ (14).

Table 2. Classification of osteogenesis imperfecta, adapted from Valdares et al. (10).

\begin{tabular}{|c|c|c|}
\hline $\begin{array}{l}\text { Osteogenesis } \\
\text { imperfecta }\end{array}$ & Inheritance & Genes \\
\hline $\begin{array}{l}\text { Nondeforming } \\
\text { osteogenesis imperfecta } \\
\text { (type I) }\end{array}$ & $\begin{array}{l}A D \\
\text { X-linked }\end{array}$ & $\begin{array}{l}\text { COL1A1, COL1A2 } \\
\text { PLS3 }\end{array}$ \\
\hline Perinatal lethal (type II) & $A D, A R$ & $\begin{array}{l}\text { COL1A1, COL1A2, } \\
\text { CRTAP, LEPRE1, PPIB, } \\
\text { BMP1, CREB3L1 }\end{array}$ \\
\hline $\begin{array}{l}\text { Progressively deforming } \\
\text { (type III) }\end{array}$ & $A D, A R$ & $\begin{array}{l}\text { COL1A1, COL1A2, } \\
\text { CRTAP, LEPRE1, PPIB, } \\
\text { FKBP10, SERPINH1, } \\
\text { SERPINF1, WNT1 }\end{array}$ \\
\hline Moderate (type IV) & $A D, A R$ & $\begin{array}{l}\text { COL1A1, COL1A2, } \\
\text { CRTAP, FKBP10, SP7, } \\
\text { SERPINF1, WNT1, } \\
\text { TMEM38B }\end{array}$ \\
\hline $\begin{array}{l}\text { With calcification of the } \\
\text { interosseous membrane } \\
\text { and/or hypertrophic } \\
\text { callus (type V) }\end{array}$ & $A D$ & IFITM5 \\
\hline
\end{tabular}

Legend: $A D$, autosomal dominant; AR, autosomal recessive.

Osteogenesis imperfecta type V, first described in 2000, is a distinct clinical entity with unique clinical, radiological, and histological features. Clinically, it is only moderately deforming. Patients have normal sclera and teeth. Radiologic diagnostic criteria include a triad of calcification of the radioulnar interosseous membrane, the presence of hypertrophic callus at fractures or post-operative sites, and radiodense metaphyseal band adjacent to growth plates (13). Histologically, it is distinguished by a mesh-like pattern of lamellation under polarized light microscopy in iliac bone samples. Ossification of the interosseous membrane of the forearm is a constant feature, which may vary in its extent, can severely limit movements of the forearm, and is associated with secondary dislocation of the radial head $(14,15)$. The formation of hypertrophic callus, if present, is the most conspicuous clinical symptom in OI type V (14, 16). Long bones are most often affected, particularly in the lower extremities (16). Hypertrophic callus can be precipitated either by a fracture or a surgery, or arises spontaneously, and can become very large or even mimic osteosarcoma $(15,17-19)$. Evolution of the lesions is variable, ranging from complete resolution to significant persisting morbidity (20).

Ol type $V$ is caused by a recurrent c. $-14 C>T$ mutation in the 5'- untranslated region of the IFITM5 gene, encoding interferon induced transmembrane protein 5 , detected in all so far described patients (21-25). Even though the disease-causing mutation is identical among patients with Ol type $\mathrm{V}$, the interindividual phenotypic variability is considerable $(23,24)$.

The present report describes long-term clinical and radiographic follow-up of two patients with OI type $\mathrm{V}$ caused by c. $-14 C>T$ in the 5' -UTR of IFTM5 with markedly different response to bisphosphonate treatment. A possible cause for a different response to the therapy was investigated.

\section{MATERIALS AND METHODS}

\subsection{Patients}

\subsubsection{Case Report 1}

The boy was born after an uneventful pregnancy and delivery to non-consanguineous parents. None of his parents had Ol. At 6 months of age, after a vaccination by injection into the thigh, a painful swelling appeared. Radiographically, an unexpected fracture of the mid-shaft of the femur with exuberant callus formation was seen. The fracture was treated conservatively and healed with time. Because of numerous fractures of the long bones in the following years, mainly of the lower extremities (3-4 per year), Ol was suspected. Deformities presented as marked antecurvatures of both tibiae and fibulae with cortical thinning and osteopenia. The patient had normal sclerae, no hearing loss and no dental abnormalities.

At the age of 8 years, a fracture of the right femur that occurred after a minor trauma was surgically treated by internal fixation with intramedullary telescopic rod along with corrective osteotomy. Swelling of the right thigh appeared two months after the surgery, with excessive and irregular new bone formation in the bone and soft tissue at the site of the fracture on $x$-rays (Figure 1A). Computerized tomography of the same area showed a large, well defined, ossified soft tissue mass with some ill-defined cortical destruction. Histologically, the lesion was diagnosed as hyperplastic callus (26). It disappeared spontaneously 6 months after the procedure. Numerous 
corrective surgical procedures and elongation of the left femur and tibia were performed during the follow-up with good functional and structural results. At 10 years of age, low bone mineral density at the lumbar spine was detected (L1-L4 z - 3.56). Normal bone density was reached ( $L 1$ - L4 z - 0,9) after 3 years of cyclic treatment with pamidronate $1 \mathrm{mg} / \mathrm{kg}$ b.w. / day for three consecutive days every three months, followed by pamidronate cycles every 6 months for 2 years, and once yearly in the last two years, before the therapy was discontinued at the age of 16 years. Bone mineral density remained normal until the last follow-up at 21 years. Before the introduction of the bisphosphonate treatment, he suffered 20 fractures, and after the introduction of the therapy only three, all three without developing hypertrophic calluses. He reached his final height at $153 \mathrm{~cm}$ at his target height of $174 \mathrm{~cm}$ (- 3.57 HSDS).

\subsubsection{Case Report 2}

The boy was born after a normal pregnancy and delivery to healthy non-consanguineous parents. There was no family history of OI. His development was normal. The first fracture occurred at the age of 2 years and 9 months, with ten additional subsequent fractures, most of them atraumatic. Several fractures were followed by the formation of hyperplastic callus: subperiosteal fracture of right tibia, fracture of the third metacarpal on the right hand, and subperiosteal fissure of the right radius.

He was admitted to the paediatric pulmonary department because of pneumonia at the age of 3 years. Radiographically, besides pulmonary infiltrates and hypoplastic lungs, a bell-shaped chest with thin dysplastic ribs was observed. The deformities of vertebra of thoracolumbar spine were present, which led to the suspected diagnosis of spondyloepiphyseal dysplasia. Because of recurrent pulmonary infections, he was admitted several times to the pulmonary department.

At the age of 15 years, he was admitted to the department of rheumatology because of painful swelling of the distal part of the left thigh. Height and weight were on the 25th and 10th centile, respectively. He did not have blue sclera or dentinogenesis imperfecta. The large thigh mass was hot, tender and hard on palpation. Skeletal survey showed thoracic kyphoscoliosis, calcified interosseus membrane of the forearms and large radio-dense mass surrounding distal part of the femur without visible fracture of the bone. Magnetic resonance imaging demonstrated a large lobulated mass of $18-20 \mathrm{~cm}$, surrounded by a thick calcified shell (Figure 1B). Histological investigation was typical for hypertrophic callus. The callus never regressed completely.
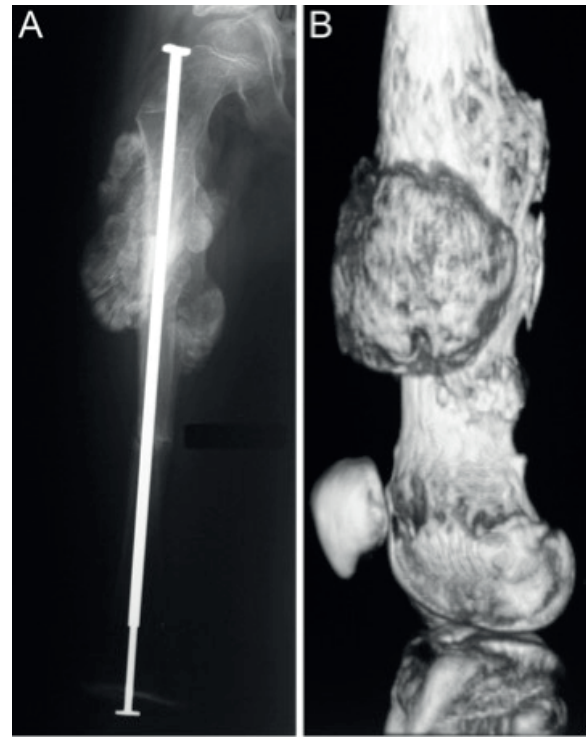

Figure 1A. Left: Patient 1. Hypertrophic callus formation appeared two months after a fracture of the right femur that was surgically treated by internal fixation with intramedullary telescopic rod along with corrective osteotomy.

Figure 1B. Right: Patient 2. Magnetic resonance imaging of a large lobulated mass of $18-20 \mathrm{~cm}$ in the distal femur surrounded by a thick calcified shell.

Bone densitometry showed low lumbar mineral density (L1 - L4 z - 3.1) and the diagnosis of OI type $V$ was established. Cyclic treatment with pamidronate $1 \mathrm{mg} / \mathrm{kg}$ b.w. / day for three consecutive days every three months was started. He was switched to the treatment with zoledronate every 6 months at 20 years of age. Despite the bisphosphonate treatment, bone mineral density did not improve (Figure 2).

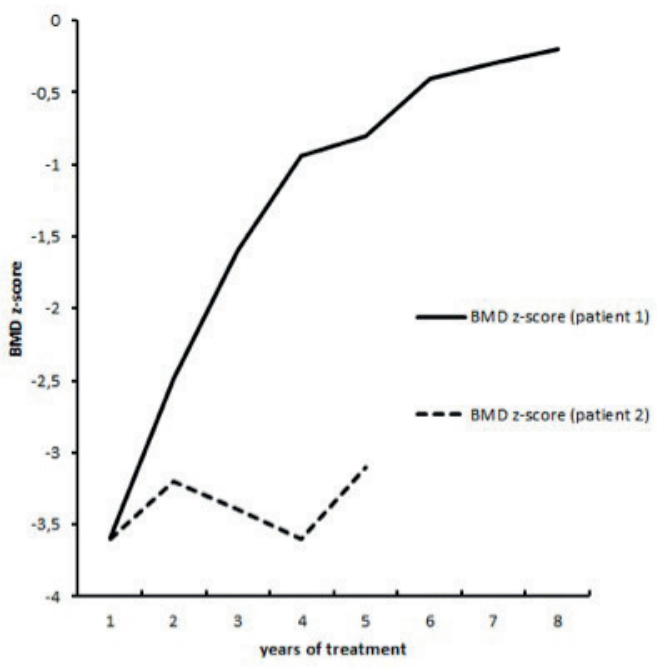

Figure 2. Bone mineral density in patients with Ol type $\mathrm{V}$ during the bisphosphonate treatment. 
During the course of the next 5 years, the patient had four more fractures, including the fractures of 4th, 5th and 6th rib on the right side, and a fracture of the left fibula with hypertrophic callus formation without regression. His final height was $168 \mathrm{~cm}(-1.41 \mathrm{HSDS})$ (Table 3).

Table 3. Clinical findings in patients with Ol type $\mathrm{V}$ caused by the c.-14C>T mutation in IFITM5.

\begin{tabular}{lcc}
\hline Clinical characteristics & Patient 1 & Patient 2 \\
\hline Age at diagnosis & 4 & 16 \\
Age at last visit & 21 & 21 \\
Height SDS & -3.57 & -1.41 \\
$\begin{array}{l}\text { Height SDS } \\
\text { Height SDS - Target Height SDS }\end{array}$ & -2.97 & -1.24 \\
BMD z score (before treatment) & -3.59 & -3.10 \\
(after treatment) & -0.20 & -3.60 \\
Number of fractures & 23 & 11 \\
Fractures at birth & - & 1 \\
Hyperplastic callus & + & +++ \\
Interosseous membrane calcification & + & + \\
Radial subluxation/luxation & - & - \\
\hline
\end{tabular}

\subsection{Mutational Analyses}

Genomic DNA was isolated from venous blood samples using the FlexiGene DNA Kit 250 (Qiagen, Hilden, Germany), according to the recommended protocol. Both exons, exon-intron boundaries and 5' -UTR of IFITM5 gene were PCR amplified using in-house designed primers (primer sequences available upon request). Sequencing was performed using BigDye Terminator v.3.1 Cycle Sequencing Kit and 3500 Genetic Analyzer capillary electrophoresis system (Life Technologies, Foster City, CA, USA). The obtained nucleotide sequences were compared to the normal IFITM5 sequence (GenBank NG_03289.1).

In both patients, the same methodology of Sanger sequencing using specific in-house designed primers (primer sequences available upon request) was used for genotyping of variants rs2297480 in farnesyl diphosphate synthase gene (FDPS) and rs3840452 in geranylgeranyl diphosphate synthase 1 gene (GGPS1).

\section{RESULTS}

No pathological genetic variations were detected in the coding region and in exon-intron boundaries of the IFITM gene. However, the c.-14C>T IFITM 5 mutation was detected in both individuals in heterozygous state.
Both patients carried major FDPS variant rs2297480 in homozygous state and were heterozygous for GGPS 1 variant rs3840452.

\section{DISCUSSION}

Both presented patients with clinical features of osteogenesis imperfecta type $V$ were positive for the previously described 5'-UTR mutation of IFTM5, found in all so far described patients (21-25). The clinical diagnosis of Ol type $\mathrm{V}$ was based on the presence of bone fragility, history of hyperplastic callus formation and calcification of the interosseous membrane of the forearm. None of our patients had radial head luxation.

Even though the disease-causing mutation is identical in patients with Ol type V, the interindividual (23) and intrafamilial phenotypic variability is considerable $(24$, 27). Patient 1 with multiple recurrent fractures over the years developed only two hypertrophic calluses, both in the right thigh. Both lesions disappeared spontaneously. Patient 2 had 11 recurrent fractures of various bones, a majority of which developed hypertrophic calluses, also at the 3rd metacarpal and at the phalange of the index finger, and some never disappeared: the last one developed at the age of 21 years, after the final height has already been reached and pubertal signs fully developed. In the study of Lee DY et al., all patients have ossification of interosseus membrane of the forearm. The severity of ossification was significantly correlated with increasing age, but not with the range of forearm rotation (27). One of the index patients showed ossification of the interosseous membrane of the lower leg as well (27). Although the investigation was performed when both our patients were already adults, only an incomplete ossification was established with slight reduction of pronation and supination of the right arm in patient 2 .

The phenotypic variability in $\mathrm{Ol}$ type $\mathrm{V}$ is highlighted by the wide range of height and $B M D$ results in this patient group $(23,24)$. It appears that some of it is due to gender differences, as males tend to have larger deficits in height and BMD (23). Our patients were both males, of the same age, and reached adulthood during the follow up. The severe growth failure in patient 1 may be related to several fractures with deformities, growth plate lesions and surgical correction of scoliosis at a relatively young age. On the other hand, patient's 2 final height was less than - 1SD below the mean for his target height despite being diagnosed and treated for osteoporosis only in late adolescence, but the fracture incidence was smaller.

Recent studies showed that intravenous pamidronate therapy has similar effects in Ol type $\mathrm{V}$ as in the other Ol types $(28,29)$. Successful treatment with intravenous zoledronate and ibadronate treatment in Ol type $\mathrm{V}$ (24) 
and other types of OI (30) was also observed. There was no correlation between phenotypic severity, the age at start of the treatment and treatment response in patients with OI types III and IV (31), as well as in patients with OI type $V(28)$. Fracture incidence decreased in all patients $(28,29)$. Before treatment with bisphosphonates, the lumbar spine areal BMD was decreased in both our patients. Patient's1 BMD steadily increased until normal values after three years of cyclic pamidronate infusions, and remained in normal range 5 years after the discontinuation of the therapy. The second patient started treatment with bisphosphonates at the age of 16,5 years, before pubertal growth spurt and several years before final height was reached; however, no increase in BMD was observed and callus formation continued. Cheung MS et al. reported a patient with Ol type $\mathrm{V}$ who has been treated by pamidronate for 9,5 years. During this time, he developed hyperplastic calluses at five different sites (20).

Farnesyl disphosphate synthase encoded by FDPS gene and geranyl-geranyl disphosphate synthase encoded by GGPS1 gene are enzymes of the mevalonate pathway, which are inhibited by bisphosphonates leading to osteoclast apoptosis. Polymorphisms in FDPS and GGPS1 genes are associated with a different response rate to bisphosphonate treatment in postmenopausal osteoporosis $(32,33)$. Analysed variants in those genes could not explain different response of bisphosphonate treatment in our patients, since both patients carried major FDPS variant rs2297480 and were heterozygous for GGSP1 variant rs3840452.

In conclusion, two patients with Ol type $\mathrm{V}$ due to recurrent c. $-14 C>$ T in the 5 ' -UTR of IFTM5 mutation had a pronounced interindividual phenotypic variability in terms of fracture incidence and hypertrophic callus formation, and very different responses to bisphosphonate treatment during 17 years follow-up, which could not be explained by analysed variants in genes involved in bisphosphonate metabolism.

\section{CONFLICTS OF INTEREST}

The authors declare that no conflicts of interest exist.

\section{FUNDING}

The study was in part financed by grants from the Slovenian Research Agency J3-6800, J3-6798, P3-0343.

\section{ETHICAL APPROVAL}

Patients and/or their parents signed written informed consent for genetic diagnostics and anonymous data publication.

\section{REFERENCES}

1. Bachrach LK, Hastie T, Wnag M-C, Narasimhan B, Marcus R. Bone mineral acquisition in healthy Asian, Hispanic, Black, and Caucasian youth: a longitudinal study. J Clin Endocrinol Metab 1999; 84: 470212.

2. Manolagas SC, Jilka RL. Bone marrow, cytokines, and bone remodeling. N Engl J Med 1995; 332: 305-11.

3. Blake GM, Naeem M, Boutros M. Comparison of effective dose to children and adults from dual X-ray absorptiometry examinations. Bone 2006; 38: 935-42.

4. World Health Organization. WHO scientific group assessement of the osteoporosis at the primary care level. Geneva: WHO, 2004.

5. Bachrach L, Sills I. Clinical report-bone densitometry in children and adolescents. Pediatrics 2011; 127: 189-94.

6. Zemel BS, Leonard MB, Kelly A, Lappe JM, Gilsanz V, Oberfield S. et al. Height adjustment in assessing dual energy X-ray absorptiometry measurements of bone mass and density in children. J Clin Endocrinol Metab 2010; 95: 1265-73.

7. Landin LA. Epidemiology of children's fractures. J Pediatr Orthop B 1997; 6: 79-83.

8. Goulding A, Jones IE, Taylor RW, Manning PJ, Williams SM. More broken bones: a 4-year double cohort study of young girls with and without distal forearm fractures. J Bone Miner Res 2000; 15: 2011-8.

9. Shaw NJ. Osteoporosis in paediatrics. Arch Dis Child Educ Pract Ed 2007; 92: 169-75

10. Warman ML, Cormier-Daire V, Hall C, Krakow D, Lachman R, LeMerrer $M$. et al. Nosology and classification of genetic skeletal disorders: 2010 revision. Am J Med Genet A 2011; 155A: 943-68.

11. Valadares ER, Carneiro TB, Santos PM, Oliveira AC, Zabel B. What is new in genetics and osteogenesis imperfecta classification? J Pediatr (Rio J) 2014; 90: 536-41.

12. Marini JC, Reich A, Smith SM. Osteogenesis imperfecta due to mutations in non-collagenous genes: lessons in the biology of bone formation. Curr Opin Pediatr 2014; 26: 500-7.

13. van Dijk FS, Zillikens MC, Micha D, Riessland M, Marcelis CL, de DieSmulders CE. et al. PLS3 mutations in X-linked osteoporosis with fractures. N Engl J Med 2013; 369: 1529-36.

14. Glorieux F, Rauch F, Plotkin H, Ward L, Travers R, Roughley P. et al. Type $\mathrm{V}$ osteogenesis imperfecta: a new form of brittle bone disease. J Bone Miner Res 2000; 15: 1650-8.

15. Rauch F, Glorieux F. Osteogenesis imperfecta. Lancet 2004; 363: 1377-85.

16. Cheung MS, Glorieux FH, Rauch F. Natural history of hyperplastic callus formation in osteogenesis imperfecta type V. J Bone Miner Res 2007; 22: 1181-6.

17. Vieira RL, Amaral DT, Jesus-Garcia FR, Saraiva G, Fernandes AR, Resnick D. Hyperplastic callus formation in osteogenesis imperfecta type V mimicking osteosacroma: 4-year follow-up with resolution. Skeletal Radiol 2006; 35: 402-5.

18. Rieker O, Kreitner KF, Karbowski A. Hyperplastic callus formation in osteogenesis imperfecta: CT and MRI findings. Eur Radiol 1998; 8: 1137-9.

19. Dobrocky I, Seidl G, Grill F. MRI and CT features of hyperplastic callus in osteogenesis imperfecta tarda. Eur Radiol 1999; 9: 665-8. 
20. Cheung MS, Azouz EM, Glorieux FH, Rauch F. Hyperplastic callus formation in osteogenesis imperfecta type $\mathrm{V}$ : follow-up of three generations over ten years. Skeletal Radiol 2008; 37: 465-7.

21. Cho TJ, Lee KE, Lee SK, Song SJ, Kim KJ, Jeon D. et al. A single recurrent mutation in the 5'-UTR of IFITM5 causes osteogenesis imperfecta type V. Am J Hum Genet 2012; 91: 343-8.

22. Semler O, Garbes L, Keupp K, Swan D, Zimmermann K, Becker J. et al. A mutation in the 5'-UTR of IFITM5 creates an in-frame start codon and causes autosomal-dominant osteogenesis imperfecta type V with hyperplastic callus. Am J Hum Genet 2012; 91: 349-57.

23. Rauch F, Moffatt P, Cheung M, Roughley P, Lalic L, Lund AM. et al. Osteogenesis imperfecta type $\mathrm{V}$ : marked phenotypic variability despite the presence of the IFITM5 c.-14C>T mutation in all patients. J Med Genet 2013; 50: 21-4.

24. Shapiro JR, Lietman C, Grover M, Lu JT, Nagamani SC, Dawson BC. et al. Phenotypic variability of osteogenesis imperfecta type $V$ caused by IFITM5 mutation. J Bone Miner Res 2013; 28: 1523-30.

25. Balasubramanian M, Parker MJ, Dalton A, Giunta C, Lindert U, Peres LC. et al. Genotype-phenotype study in type V osteogenesis imperfecta. Clin Dysmorphol 2013; 22: 93-101

26. Lamovec J, Možina E, Baebler B. Hyperplastic callus formation in osteogenesis imperfecta. Ann Diag Pathol 2003; 7: 231-5.

27. Lee DY, Cho TJ, Choi IH, Chung CY, Yoo WY, Kim JH. et al. Clinical and radiological manifestations of osteogenesis imperfecta type V. J Korean Med Sci 2006; 21: 709-14.
28. Zeitlin L, Rauch F, Travers R, Munns C, Glorieux FH. The effect of cyclical intravenous pamidronate in children and adolescents with osteogenesis imperfecta Type V. Bone 2006; 38; 13-20.

29. Fleming F, Woodhead HJ, Briody JN, Hall J, Cowell CT, Ault J. et al. Cyclic bisphosphonate therapy in osteogenesis type V. J Pediatr Child Health 2005; 41: 147-51.

30. Vuorimies I, Toiviainen-Salo S, Hero M, Mäkitie O. Zoledronic acid treatment in children with osteogenesis imperfecta. Horm Res Paediatr 2011; 75: 346-53.

31. Zacharin M, Bateman J. Pamidronate treatment of osteogenesis imperfecta-lack of correlation between clinical severity, age at onset of treatment, predicted collagen mutation and treatment response. J Pediatr Endocrinol Metab 2002; 15: 163-74.

32. Marini F. Falchetti A, Silvestri S, Bagger Y, Luzi E, Tanini A. et al. Modulatory effect of farnesyl pyrophosphate synthase (FDPS) rs2297480 polymorphism on the response to long-term aminobisphosphonate treatment in postmenopausal osteoporosis. Curr Med Res Opin 2008; 24: 2609-15.

33. Choi HJ, Choi JY, Cho SW, Kang D, Han KO, Kim SW. et al. Genetic polymorphism in geranylgeranyl diphosphate synthase (GGSP1) predicts bone density response to bisphosphonate therapy in Korean women. Yonsei Med J 2010; 51: 231-8. 